\title{
PENGEMBANGAN LEMBARAN KERJA SISWA (LKS) EKPERIMEN BERBASIS GUIDED-INQUIRY MATERI LAJU REAKSI UNTUK SISWA SMA / MA
}

\author{
Andromeda $^{1)}$ Yerimadesi $^{\text {2) }}$ Iwefriani $^{3)}$ \\ ${ }^{1)}$ Staf Pengajar Jurusan Kimia, FMIPA Universitas Negeri Padang \\ ${ }^{2)}$ Staf Pengajar Jurusan Kimia, FMIPA Universitas Negeri Padang \\ ${ }^{3)}$ Mahasiswa Prodi Pendidikan Kimia, FMIPA Universitas Negeri Padang \\ andromedasaidir@yahoo.com
}

\begin{abstract}
This study aims to produce teaching materials based material reaction rate guided inquiry (learning cycle: the phase of exploration, discovery / establishment of the concept and application) in the form of a valid experiment worksheets and practical use in learning chemistry in SMA / MA. This type of research included in Research and Development $(R \& D)$. The development model used in this study is the four-D (4-D). The research instrument is the validation sheet and questionnaire. Data from the study consists of three aspects, namely, the validity, the practicalities and effectiveness of teaching materials. Data validity and practicalities processed using Cohen's Kappa formula, and the effectiveness of data using a percentage In this study is limited to the validity and practicalities. Validation of teaching materials from the aspect of content, language and graffiti and feasibility of construction. Data from the validator obtained an average score moment kappa was 0.87 , and the results of practical analysis conducted with a limited test in MAN 3 Padang obtained an average score of 0.84 practicality value of 0.78 of teachers and students. From the analysis worksheets that showed 86 $\%$ of students working on critical questions and exercises contained in LKS experiments that have been made can be answered students. These results indicate that LKS guided inquiry-based experiments developed extremely valid and practical use in learning chemistry
\end{abstract}

Keywords : LKS Experiment, Guided Inquiry, Rate of reaction, 4-D Model

\section{PENDAHULUAN}

Ilmu kimia merupakan salah satu cabang Ilmu Pengetahuan Alam (IPA) berlandaskan eksperimen (experimental science). konsepkonsep yang terdapat dalam materi kimia dapat dibuktikan melalui kegiatan eksperimen. Salah satu materi kimia yang membutuhkan kegiatan eksperimen yaitu materi laju reaksi. Laju reaksi merupakan perubahan konsentrasi reaktan atau produk terhadap waktu (Chang, 2010). Materi ini dipelajari di kelas XI SMA/MA semester satu. Pada materi ini siswa harus mampu menjelaskan faktor-faktor yang mempengaruhi laju reaksi yaitu konsentrasi, luas permukaan, suhu dan katalis, serta mampu menghitung dan menentukan orde reaksi, persamaan laju reaksi dan tetapan laju reaksi melalui eksperimen.

Pembelajaran pada Kurikulum 2013 mendorong siswa untuk memiliki kemampuan berpikir kritis, kreatif, dan inovatif (Kurinasih dkk., 2014). Siswa harus aktif dan mandiri dalam pembelajaran sedangkan guru berperan sebagai fasilitator dan motivator. Kegiatan pembelajaran melalui eksperimen akan membuat proses pembelajaran mengamati, menanya, mengumpulkan data, mengasosiasikan, dan mengkomunikasikan (5M) yang dituntut kurikulum 2013 dapat terlaksana (Kemendiknas., 2014). Melalui kegiatan eksperimen dapat memberikan pengamatan langsung terhadap gejala-gejala atau proses-proses sains, melatih kemampuan berpikir ilmiah, menanamkan dan mengembangkan sikap ilmiah. Selain itu kegiatan eksperimen dapat membuat pembelajaran lebih bermakna dan mendalam (Astuti, dkk. 2012).

Kegiatan eksperimen dalam pembelajaran lebih berpusat pada siswa (student centered), siswa yang berperan aktif, serta dapat menemu- 
kan suatu konsep sendiri melalui kerja ilmiah atau kegiatan eksperimen. Namun, pada umumnya di sekolah kegiatan eksperimen dilakukan setelah pembelajaran teori sehingga eksperimen cendrung bersifat mengkorfirmasi konsep yang diperoleh. Kegiatan eksperimen seperti ini membuat siswa hanya melakukan serangkaian percobaan berdasarkan petunjuk yang ada pada Lembaran Kerja Siswa (LKS) saja, sehingga keterlibatan siswa dalam penemuan konsep rendah. Sebaiknya melalui kegiatan eksperimen siswa hendaknya mampu menghubungkan fakta dari hasil percobaan dengan teori yang ada dan mampu menemukan konsep sendiri. Sehingga konsep yang diperoleh akan lebih lama diinga$\tan$ siswa.

Dalam menunjang kegiatan eksperimen yang dapat mendorong siswa terlibat aktif dalam menemukan konsep atau pengetahuan sendiri, dibutuhkan LKS eksperimen berbasis guided inquiry. Pembelajaran inkuiri merupakan suatu kegiatan pembelajaran yang menekankan pada proses berpikir kritis dan analitis untuk mencari dan menemukan sendiri jawaban dari suatu masalah yang dipertanyakan (Sanjaya, 2006; Driessen, 2011).

LKS eksperimen berbasis guided inquiry yang dikembangkan disusun bedasarkan tahapan pembelajaran guided inquiry menurut Hanson (2005) yang terdiri dari 5 tahap yaitu orientasi, eksplorasi, penemuan atau pembentukan konsep, aplikasi dan penutup.

Orientasi merupakan tahap awal dari pembelajaran. Tahap ini dapat memberikan motivasi, menghasilkan rasa ingin tahu dan membuat hubungan ke pengetahuan berikutnya dengan memberikan materi prasyarat, indikator, tujuan percobaan serta kegiatan merumuskan hipotesis. Pada tahap eksplorasi siswa mengamati dan menganalisis data atau informasi melalui kegiatan eksperimen untuk menguji hipotesis. Pada tahap pembentukan konsep, siswa akan mengembangkan dan memahami konsep yang dipelajari melalui pertanyaan kritis (critical thinking questions) yang diberikan. Pertanyaanpertanyaan kritis ini akan memandu siswa membangun dan mengembangkan konsep dasar dari pembelajaran (Straumanis, 2010). Untuk lebih memahami konsep yang telah didapatkannya, siswa diberikan soal-soal latihan. Tahap ini me- rupakan tahap aplikasi. Sedangkan pada penutup, siswa membuat kesimpulan.

Beberapa penelitian terdahulu menyimpulkan bahwa pengalaman laboratorium /eksperimen dalam pembelajaran dapat meningkatkan pencapaian tujuan dan hasil belajar siswa (Hofstein dkk., 2007; Hofstein dkk., 2003). Penelitian tentang penerapan pembelajaran guided inquiry menyimpulkan bahwa guided inquiry dapat meningkatkan motivasi siswa dalam pembelajaran sains (Patrick dkk., 2009). Penelitian lain juga menyatakan bahwa siswa yang belajar dengan menggunakan strategi guided inquiry lebih mudah mengerti dan memahami konsep pelajaran sehingga dapat meningkatkan prestasi siswa (Bilgin, 2009 ; Myers dkk., 2012).

Penelitian pengembangan bahan ajar berbasis guided inquiry telah dilakukan antara lain oleh Andromeda dkk., (2014) mengembangkan LKS berbasis guided inquiry dengan representasi chemistry trianggle untuk materi struktur atom; Iryani dkk., (2014) mengembangkan LKS berbasis guided inquiry dengan representasi chemistry trianggle untuk materi asam dan basa; Andromeda dkk., (2015) mengembangkan LKS berbasis guided inquiry dengan representasi chemistry trianggle untuk materi hidrolisis garam dan Andromeda dkk., (2015) mengembangkan LKS eksperimen berbasis guided inquiry untuk topik sistem koloid. Semua penelitian yang telah dilakukan melaporkan bahwa LKS yang dikembangkan valid dan praktis digunakan dalam proses pembelajaran.

Berdasarkan latar belakang di atas, maka penelitian pengembangan bahan ajar dalam bentuk LKS eksperimen berbasis guided inquiry pada materi laju reaksi untuk pembelajaran kimia SMA penting dilakukan. Penelitian ini bertujuan menghasilkan bahan ajar dalam bentuk LKS eksperimen berbasis guided inquiry pada materi laju reaksi yang valid dan praktis digunakan dalam pembelajaran kimia di SMA/MA. Diharapkan hasil penelitian ini dapat mengatasi kesulitan guru dan peserta didik dalam mendapatkan LKS untuk eksperimen laboratorium yang berorientasi proses, Melalui LKS eksperimen ini diharapkan dapat membantu siswa dalam menemukan sendiri konsep dari materi laju reaksi, sesuai tuntutan kurikulum 2013. 


\section{METODE PENELITIAN}

Penelitian ini termasuk jenis penelitian Research and Development ( $\mathrm{R} \& \mathrm{D})$, yaitu penelitian yang digunakan untuk menghasilkan suatu produk dan menguji keefektifan produk tersebut (Sugiyono, 2011). Produk dalam penelitian ini yaitu LKS eksperimen laju reaksi berbasis guided inquiry untuk pembelajaran kimia di SMA/MA

LKS eksperimen laju reaksi berbasis guided inquiry dikembangkan dengan model pengembangan perangkat pembelajaran four- $D$ Models oleh Thiagarajan, Semmel dan Semmel (1974). Model ini terdiri dari 4 tahap, yaitu $d e$ fine, design, develop dan disseminat (Trianto. 2012). Penelitian ini baru dilakukan sampai tahap develop yaitu uji validitas dan praktikalitas terhadap produk yang dihasilkan.

Langkah-langkah dalam pengembangan LKS adalah sebagai berikut ; 1) Tahap define (pendefinisian), tahap ini terdiri atas 5 langkah pokok yaitu analisis ujung depan, analisis siswa, analisis tugas, analisis konsep, perumusan tujuan pembelajaran ; 2) Tahap design (perancangan), tahap perancangan bertujuan untuk merancang LKS eksperimen berbasis guided inquiry untuk materi laju reaksi kelas XI SMA/MA. LKS yang dirancang mengikuti siklus belajar guided inquiry Hanson (2005) yang meliputi orientasi, eksplorasi, pembentukan konsep, aplikasi dan penutup. Untuk format penulisan LKS sesuai buku panduan pengembangan bahan ajar dari Depdiknas (2008); 3) Tahap develop (pengembangan). Tahap pengembangan bertujuan untuk menghasilkan LKS eksperimen laju reaksi berbasis guided inquiry yang valid dan praktis digunakan dalam pembelajaran. Tahap ini terdiri dari tiga langkah, yaitu uji validitas, revisi, dan uji praktikalitas.

Instrumen dalam penelitian ini adalah angket validasi yang ditujukan kepada dosen kimia FMIPA UNP dan guru kimia SMA/MA, dan angket praktikalitas yang terdiri dari angket respon guru dan siswa. Angket validasi digunakan untuk menilai bahan ajar dari segi komponen isi, komponen konstruk, komponen kebahasaan, dan komponen kegrafikaan. Setelah melakukan uji validitas, dilakukan revisi terha- dap LKS. Revisi dilakukan sesuai saran yang diberikan oleh validator. Angket praktikalitas bertujuan untuk mengetahui tingkat kepraktisan pemakaian LKS berbasis guided inquiry selama proses pembelajaran. Kepraktisan ini sebagai suatu ukuran yang menentukan suatu bahan ajar dapat dikatakan baik atau tidak (Mudjijo, 1995).

Teknik analisis data yang digunakan untuk analisis validitas dan praktikalitas (angket respon guru dan siswa) yaitu dengan menggunakan formula moment kappa (pers. 1) (Boslaugh, dkk., 2008). Untuk melihat kepraktisan juga dilakukan analisis jawaban siswa pada LKS yang digunakan dalam pembelajaran dengan teknik persentase.

moment kappa $(k)=\frac{P-P e}{1-P e}$

Tabel 1. Kategori Keputusan berdasarkan momen kappa (k)

\begin{tabular}{cc}
\hline Interval & Kategori \\
\hline $0,81-1,00$ & Sangat tinggi \\
\hline $0,61-0,80$ & Tinggi \\
\hline $0,41-0,60$ & Sedang \\
\hline $0,21-0,40$ & Rendah \\
\hline $0,01-0,20$ & Sangat rendah \\
\hline$\leq 0,00$ & Tidak valid \\
\hline
\end{tabular}

\section{HASIL DAN PEMBAHASAN}

\section{Hasil Penelitian}

Sesuai tujuan dan prosedur penelitian, telah dihasilkan bahan ajar LKS eksperimen berbasis guided inquiry pada materi laju reaksi, mengunakan model pengembangan perangkat pembelajaran four-D. Hasil yang diperoleh adalah sebagai berikut ini.

\subsection{Tahap Define (Pendefinisian)}

Pada tahap ini dilakukan analisis ujung depan, analisis siswa, analisis tugas, analisis konsep dan perumusan tujuan pembelajaran. Pada analisis ujung depan dilakukan analisis terhadap masalah yang dihadapi guru dan siswa dalam pembelajaran kimia. Hasil analisis menunjukkan bahwa proses pembelajaran lebih diwarnai teachers centered daripada student centered, dan masih belum optimalnya pembelajaran berbasis eksperimen. Pelaksanaan 
pembelajaran yang terdapat dalam Kurikulum 2013 menyatakan bahwa dalam proses pembelajaran menuntut kemampuan komunikasi, berpikir kritis dan proses yang berpusat pada siswa. Hal ini menunjukkan bahwa siswa yang harus aktif dalam membangun pengetahuannya dan guru lebih berperan sebagai fasilitator dan motivator.

Kegiatan pembelajaran melalui eksperimen akan membuat proses pembelajaran mengamati, menanya, mengumpulkan data, mengasosiasikan, dan mengkomunikasikan $(5 \mathrm{M})$ yang dituntut kurikulum 2013 dapat terlaksana dengan siswa sebagai pusat pembelajaran. Selanjutnya dilakukan analisis Kompetensi Inti (KI) dan Kompetensi Dasar (KD) untuk materi laju reaksi sesuai kurikulum 2013. Berdasarkan analisis tersebut dirancanglah bahan ajar LKS eksperimen berbasis guided inquiry, agar tuntutan kurikulum dapat tercapai. Penggunaan bahan ajar LKS eksperimen berbasis guided inquiry materi laju reaksi ini dibuat berdasarkan siklus belajar guided inquiry Hanson (2005).

Hasil Analisis Siswa SMA/MA diperoleh : 1) Kemampuan akademis siswa pada materi laju reaksi secara umum bersifat heterogen. Artinya ada siswa yang memiliki tingkat kemampuan akademis tinggi, sedang dan ada juga yang rendah ; 2) Motivasi belajar siswa untuk mempelajari materi laju reaksi bervariasi, namun secara umum siswa sangat termotivasi untuk melakukan kegiatan eksperimen di laboratorium ; 3) Usia siswa kelas XI SMA berkisar antara 16-17 tahun. Menurut Piaget perkembangan kognitif remaja umur 16-17 tahun berada pada tahap formal operation stage, yaitu tahap terakhir dari tahapan perkembangan kognitif. Pada tahap ini remaja memiliki kemampuan untuk berfikir secara abstrak, menalar secara logis dan menarik kesimpulan dari informasi yang tersedia (Yusuf dkk., 2011).

Analisis Tugas. Berdasarkan kurikulum 2013, kompetensi dasar dari materi laju reaksi meliputi kompetensi dasar 3.6, 3.7, 4.6, 4.7(Silabus Kimia SMA 2013). Keempat kompetensi dasar dari materi laju reaksi dijabarkan menjadi 5 indikator pembelajaran. Analisis Konsep. Konsep utama pada materi laju reaksi meliputi konsep laju reaksi, persamaan laju reaksi, orde reaksi, konstanta laju reaksi (tetapan laju reaksi), serta faktor-faktor yang mempengaruhi laju reaksi. Berdasarkan analisis konsep, maka konsep-konsep yang dapat dilakukan eksperimen untuk SMA/MA kelas XI yaitu tentang faktor-faktor yang memepengaruhi laju reaksi (konsentrasi, luas permukaan, suhu dan katalis) serta penentuan orde reaksi dan tetapan laju reaksi.

Analisis tujuan pembelajaran merupakan tahap pengubahan hasil analisis tugas dan analisis konsep ke dalam tujuan pembelajaran. Analisis ini dijadikan dasar untuk mengkonstruksi bahan ajar yang dikembangkan. Perumusan Tujuan Pembelajaran dijabarkan menjadi 5 tujuan pembelajaran.

\subsection{Tahap Design (Perancangan)}

Pada tahap ini dihasilkan rancangan awal dari LKS eksprimen laju reaksi berbasis guided inquiry. Format rancangan dalam LKS eksperimen laju reaksi berbasis guided inquiry didasarkan pada Buku Panduan Pengembangan Bahan Ajar Depdiknas tahun 2008. Format ini telah disesuaikan dengan tahapan pembelajaran guided inquiry yang meliputi orientasi, eksplorasi, pembentukan konsep, aplikasi dan penutup.

Hal-hal yang dilakukan pada tahap design perancangan (perancangan) antara lain yaitu melakukan survei alat dan bahan yang tersedia ke beberapa sekolah yaitu SMAN 13 Padang, SMAN 7 Padang, MAN 3 Padang dan SMAN 1 Kecamatan Kapur IX. Survei alat dan bahan yang tersedia bertujuan untuk menyesuaikan kegiatan eksperimen yang akan dirancang pada LKS eksperimen yang dikembangkan. Seperti pada percobaan pengaruh luas permukaan terhadap laju reaksi, alat-alat yang digunakan yaitu gelas piala $100 \mathrm{~mL}$, stopwatch, gelas ukur 25 $\mathrm{mL}$, neraca dan pipet tetes. Sedangkan bahan yang digunakan yaitu $\mathrm{HCl}$ dan pualam $\left(\mathrm{CaCO}_{3}\right)$ dalam bentuk serbuk, butiran dan kepingan. Semua alat-alat dan bahan-bahan tersebut pada umumnya tersedia disekolah.

Setelah mengetahui alat dan bahan yang tersedia di sekolah, maka dirancang prosedur kerja di Laboratorium Kimia FMIPA UNP yang disesuaikan dengan alat dan bahan yang tersedia di sekolah. Prosedur kerja yang dirancang 
berbasis green chemistry yaitu menggunakan zat kimia dalam jumlah yang sedikit, yang bertujuan untuk meminimalisir limbah dari kegiatan eksperimen. Selain itu, penggunaan zat dalam jumlah yang sedikit agar waktu pelaksanaan kegiatan eksperimen lebih efisien.

Bagian-bagian dari LKS eksperimen laju reaksi berbasis guided inquiry yang sudah selesai dirancang terdiri dari (1) halaman depan (cover), (2) kata pengantar, (3) daftar isi, (4) daftar gambar, (5) daftar tabel, (6) tatatertib laboratorium, (7) pengenalan alat-alat laboratorium, (8) petunjuk penggunaan LKS, (9) Kompetensi yang akan dicapai siswa, (10) materi prasyarat, (11) informasi, (12) kolom hipotesis, (13) alat dan bahan serta prosedur kerja, (14) tabel pengamatan, (15) pertanyaan kritis (critical questions), (16) latihan, (17) kesimpulan, (18) kepustakaan.

\subsection{Tahap Develop (Pengembangan)}

Tahap pengembangan bertujuan untuk menghasilkan LKS eksperimen laju reaksi berbasis guided inquiry kelas XI SMA/MA yang valid dan praktis untuk digunakan dalam proses pembelajaran.

\section{a. Uji Validitas}

Uji validitas bertujuan untuk mengetahui kategori kevalidan dari LKS eksperimen laju reaksi berbasis guided inquiry. Rata-rata moment kappa hasil uji validitas terhadap komponen isi, penyajian, kebahasaan dan kegrafisan dari LKS eksperimen laju reaksi berbasis guided inquiry dapat dilihat pada Tabel 2.

Tabel 2. Rata-rata moment kappa validitas LKS laju reaksi berbasis guided inquiry

\begin{tabular}{|c|l|c|c|}
\hline No & \multicolumn{1}{|c|}{$\begin{array}{c}\text { Aspek yang } \\
\text { dinilai }\end{array}$} & $\begin{array}{c}\text { Rata-rata } \\
\text { moment } \\
\text { kappa }\end{array}$ & $\begin{array}{c}\text { Kategori } \\
\text { kevalidan }\end{array}$ \\
\hline 1. & Komponen isi & 0,80 & Tinggi \\
\hline 2. & $\begin{array}{l}\text { Komponen } \\
\text { penyajian }\end{array}$ & 0,98 & $\begin{array}{c}\text { Sangat } \\
\text { tinggi }\end{array}$ \\
\hline 3. & $\begin{array}{l}\text { Komponen } \\
\text { kebahasaan }\end{array}$ & 0,90 & $\begin{array}{l}\text { Sangat } \\
\text { tinggi }\end{array}$ \\
\hline 4. & $\begin{array}{l}\text { Komponen } \\
\text { kegrafisan }\end{array}$ & 0,84 & $\begin{array}{l}\text { Sangat } \\
\text { tinggi }\end{array}$ \\
\hline
\end{tabular}

\section{b. Uji Praktikalitas}

Data praktikalitas diperoleh dari pemberian angket kepada guru kimia (angket respon guru) dan siswa (angket respon siswa). LKS yang dikembangkan juga diuji cobakan dalam kegiatan pembelajaran, siswa mengisi LKS sesuai yang dilakukan selama pembelajaran. Hasil analisis data praktikalitas LKS eksperimen laju reaksi berbasis guided inquiry dapat dilihat pada Tabel 3. Persentase siswa yang menjawab LKS dengan benar ada pada Tabel 4

Tabel 3. Hasil Analisis Data Penilaian Praktikalitas LKS dari Angket Respon Guru dan Siswa

\begin{tabular}{|l|l|l|l|}
\hline No & Angket & $\begin{array}{c}\text { Momen } \\
\text { kappa }\end{array}$ & $\begin{array}{c}\text { Kategori } \\
\text { kepraktisan }\end{array}$ \\
\hline 1 & Respon guru & 0,84 & Sangat tinggi \\
\hline 2 & Respon siswa & 0,78 & tinggi \\
\hline
\end{tabular}

Tabel 4. Persentase Siswa yang mengisi LKS Eksperimen berbasis guided inquiry dengan benar

\begin{tabular}{|l|l|c|c|}
\hline No & $\begin{array}{l}\text { Komponen LKS } \\
\text { yang diisi siswa }\end{array}$ & $\begin{array}{c}\text { \% siswa yang } \\
\text { mengisi den- } \\
\text { gan benar }\end{array}$ & $\begin{array}{c}\% \\
\text { Rata- } \\
\text { Rata }\end{array}$ \\
\hline 1 & $\begin{array}{l}\text { Merumuskan } \\
\text { hipotesis }\end{array}$ & 84 & \multirow{2}{*}{86} \\
\hline 2 & $\begin{array}{l}\text { Mengisi tabel } \\
\text { pengamatan }\end{array}$ & 90 & \multirow{2}{*}{8} \\
\hline 3 & $\begin{array}{l}\text { Menjawab perta- } \\
\text { nyaan kunci }\end{array}$ & 86 & \\
\hline 4 & $\begin{array}{l}\text { Mengerjakan } \\
\text { latihan }\end{array}$ & 86 & \\
\hline 5 & $\begin{array}{l}\text { Mengambil Ke- } \\
\text { simpulan }\end{array}$ &
\end{tabular}

\section{Pembahasaan}

Uji validitas bertujuan untuk menilai kevalidan LKS eksperimen laju reaksi berbasis guided inquiry yang dihasilkan. Uji validitas dilakukan oleh lima orang validator yang terdiri dari 3 orang dosen kimia FMIPA UNP dan 2 orang guru kimia SMA/MA. Untuk menguji validitas konstruk instrumen, dapat digunakan pendapat ahli (judgment experts) yang jumlahnya minimal tiga orang (Sugiyono, 2008) Ada empat komponen dari LKS eksperimen laju reaksi berbasis guided inquiry yang dinilai oleh validator, yaitu komponen isi, komponen penyajian (konstruksi), komponen kebahasan dan komponen kegrafikaan. Nilai rata-rata moment kappa komponen isi LKS eksperimen laju reaksi berbasis guided inquiry yaitu 0,80 dengan kate- 
gori kevalidan tinggi. Hal ini berarti materi yang terdapat dalam LKS eksperimen ini sudah sesuai dengan tuntutan kompetensi dasar. Pernyataan pada kotak hipotesis yang dibuat dapat membantu siswa merumuskan hipotesis. Langkah kerja dan pertanyaan kritis sudah sesuai dengan tujuan yang ingin dicapai. Informasi dan tabel pengamatan dapat membantu siswa dalam menjawab critical questions. Dan pertanyaan kritis yang diajukan dapat membimbing siswa menemukan konsep-konsep pada materi laju reaksi. Hal ini sesuai dengan fungsi dari pertanyaan kritis dalam pembelajaran guided inquiry yaitu pertanyaan yang membimbing siswa dalam mengeksplorasi model dan menemukan konsep (Hanson, 2006).

Nilai rata-rata moment kappa komponen penyajian LKS eksperimen laju reaksi berbasis inkuiri terbimbing yaitu 0,98 dengan kategori kevalidan sangat tinggi. Hal ini menunjukkan bahwa LKS eksperimen ini sudah disusun secara sistematis sesuai dengan tahapan pembelajaran inkuiri terbimbing yang terdiri dari orientasi, eksplorasi, pembentukan konsep. aplikasi dan penutup. Langkah-langkah pembelajaran ini di integrasikan dalam LKS sesuai pnduan pengembangan bahan ajar oleh Depdiknas (2008),

Nilai rata-rata moment kappa komponen kebahasaan LKS eksperimen laju reaksi berbasis guided inquiry yaitu 0,90 dengan kategori kevalidan sangat tinggi. Hal ini menunjukkan bahwa bahasa yang digunakan secara keseluruhan telah sesuai dengan kaidah bahasa Indonesia yang baik, jelas dan mudah dimengerti sehingga diharapkan dapat membantu siswa memahami materi laju reaksi dengan baik.

Nilai rata-rata moment kappa komponen kegrafikaan LKS eksperimen laju reaksi berbasis guided inquiry yaitu 0,84 dengan kategori kevaidan sangat tinggi. Hal ini menunjukkan bahwa jenis dan ukuran huruf yang digunakan dalam LKS jelas terbaca, gambar yang terdapat dalam LKS terlihat jelas, layout teratur dan warna yang digunakan dapat menarik perhatian siswa.

Analisis Kepraktisan dari Angket Respon Guru. Praktikalitas LKS eksperimen laju reaksi berbasis inkuiri terbimbing dilihat dari keterpakaian produk dari hasil uji coba terbatas di lapangan menyangkut kepraktisan dan keter- laksanaan produk yang dikembangkan. Uji praktikalitas dilakukan oleh 3 orang guru kimia SMA.

Berdasarkan hasil pengolahan data diperoleh skor rata-rata praktikalitas LKS eksperimen laju reaksi berbasis guided inquiry sebesar 0,84 dengan kategori kepraktisan sangat tinggi. Hal ini menunjukkan bahwa LKS eksperimen yang dihasilkan memudahkan guru dalam mencapai tujuan pembelajaran dan memudahkan guru untuk meningkatkan aktivitas siswa dalam pembelajaran. Hal ini sejalan dengan fungsi bahan ajar yaitu (1) pedoman bagi guru dalam mengarahkan semua aktivitasnya dalam proses pembelajaran, (2) pedoman bagi siswa yang akan mengarahkan semua aktivitasnya dalam proses pembelajaran, (3) alat evaluasi pencapaian/penguasaan hasil belajar (Depdiknas, 2008). Dapat disimpulkan bahwa LKS eksperimen materi laju reaksi yang dihasilkan dapat digunakan oleh guru dalam melaksanakan pembelajaran.

Analisis Kepraktisan dari Angket Respon Siswa. Praktikalitas LKS eksperimen laju reaksi berbasis guided inquiry juga ditentukan oleh hasil angket respon siswa. Berdasarkan analisis data hasil uji praktikalitas siswa diperoleh nilai rata-rata moment kappa sebesar 0,78 dengan kategori praktikalitas tinggi. Interpretasi keseluruhan terhadap praktikalitas yang direspon siswa adalah LKS eksperimen laju reaksi berbasis guided inquiry memudahkan siswa memahami dan mengingat konsep-konsep pada materi laju reaksi, pertanyaan kritis dapat membimbing siswa menemukan konsep, warna gambar dan tabel pengamatan dapat menarik perhatian siswa. Hal ini menunjukkan LKS eksperimen praktis digunakan dalam proses pembelajaran. Karena pertimbangan praktikalitas dapat dilihat dari aspek-aspek kemudahan penggunaan, waktu yang diperlukan dalam pelaksanaan dan daya tarik bahan ajar terhadap minat siswa (Sukardi. 2011).

Dari analisis LKS eksperimen berbasis guided inquiry yang diisi siswa dalam kegiatan pembelajaran (Tabel 4) menunjukkan bahwa rata-rata $86 \%$ siswa sudah bisa mengisi LKS dengan benar. Hal ini menunjukan bahwa LKS 
yang dikembangkan ini praktis digunakan. LKS dapat menuntun siswa menghubungkan fakta yang didapat pada hasil praktikum dengan teori yang ada dalam informasi, menjawab pertanyaan pertanyaan kritis yang memandu siswa untuk menemukan konsep, mengaplikasikan dengan mengerjakan latihan dan membuat kesimpulan. Penggunaan warna dan desain pada LKS eksperimen dapat meningkatkan motivasi belajar siswa (Yusuf dkk., 2011).

Dari pembahasan di atas dapat disimpulkan bahwa LKS eksperimen berbasis guided inquiry memiliki beberapa kelebihan yaitu: 1) dengan adanya model dan pertanyaan kritis yang terdapat pada LKS, akan mendorong siswa untuk terlibat aktif dalam mencari dan menemukan konsep sendiri melalui kegiatan eksperimen. Konsep yang diperoleh sendiri akan lebih lama diingatan siswa, 2) LKS eksperimen berbasis guided inquiry berisi latihan dan soal yang dapat meningkatkan pemahaman siswa tentang materi yang dipelajari, 3) LKS eksperimen berbasis guided inquiry ini disajikan dengan tampilan yang menarik, dilengkapi dengan warna, sehingga dapat meningkatkan motivasi dan minat belajar siswa.

\section{KESIMPULAN}

Berdasarkan penelitian yang telah dilakukan, maka telah dihasilkan LKS eksperimen berbasis guided inquiry materi laju reaksi kelas XI tingkat SMA/MA dengan menggunakan model pengembangan four-D. LKS yang dihasilkan sudah diuji kevalidan dan kepraktisannya. Berdasarkan hasil uji validitas dan praktikalitas dapat disimpulkan bahwa LKS eksperimen laju reaksi berbasis guided inquiry memiliki kategori kevalidan sangat tinggi dan kepraktisan tinggi

\section{DAFTAR PUSTAKA}

Andromeda, Bayharti, Mentari Deliputri 2015. The Development of Guided InquiryBased Worksheet for Laboratory Work on Topic of Colloidal System For Senior High School Instruction, Prosiding Seminar International ICOMSET FMIPA UNP 2015

Andromeda, Iryani, Mawardi, Shavira Meidina Irham. 2015. Pengembangan Bahan Ajar
Hidrolisis Garam Berbasis GuidedInquiry dengan Representasi ChemistryTriangle Untuk Siswa SMA/MA, Prosiding Seminar Nasional FMIPA UNP 2015

Andromeda, Iryani, Rahmi Susmiati. 2014. Pengembangan Bahan Ajar Berbasis Guided Inquiry dengan Representasi Chemistry Triangle pada Materi Struktur Atom untuk Siswa SMA. Prosiding ISBN 978-602-70491-0-9, SEMIRATA 2014 Bidang MIPA BKS-PTN-Barat, IPB : 916

Astuti, Rina, dkk. 2012. Pembelajaran IPA dengan Pendekatan Keterampilan Proses Sains Menggunakan Metode Eksperimen Bebas Termodifikasi dan Eksperimen Terbimbing Ditinjau dari Sikap Ilmiah dan Motivasi Belajar Siswa. Jurnal Inkuiri, Vol 1, No 1.

Bilgin, Ibrahim. 2009. The Effects of Guided Inqury Instruction Incorporating, a Cooperative Learning Approach on University Students' Achievement of Acid and Bases Concepts and Attitude Toward Guided Inqury Instruction. SRE, 4 (10): 1038-1046

Boslaugh, Sarah dan Paul A. W. 2008. Statistics in a Nutshell, a desktop quick reference. Beijing, "Cambridge, Famham, Köln, Sebastopol, Taipei,Tokyo: O'reilly.

Chang, Raymond. 2010. Chemistry, 10th edition, The McGraw-Hills Companie. Inc., 1221 Avenue of the Americas : New York.

Depdiknas. 2008. Panduan Pengembangan Bahan Ajar. Jakarta: Departemen Pendidikan Nasional, Direktorat Jenderal Manajemen Pendidikan Dasar dan Menengah, Direktorat Pembinaan Sekolah Menengah Atas

Driessen Michelle. 2011. ChemNews, Departmen of Chemistry Newsletter, Collegeof Science\& Engineering University of Minnesota

Hanson, David. M. 2006. Instructor's Guided to Process-Oriented Guided-Inquiry Learning. Lisle, IL: Pacific Crest.

Hanson, David. M. 2005. Designing ProcessOriented Guided-Inquiry Activities. In Faculty Guidedbook: A Comprehensive Tool For Improving Faculty Performance, ed. S. W. Beyerlein and D. K. Apple. Lisle, IL: Pacific Crest. 
Hofstein, Avi dan Rachel Mamlok-Naaman. 2007. The Laboratory in Science Education. The State of the Art. Chemistry Education Research and Practice e journal.2007, 8(2), 105-107.

Hofstein, A and Lunetta V.N., 2003 The Laboratory in Science Education: for the 21 st century, Science Education Research 22, 28-54.

Iryani, Mawardi, Andromeda, Illona Putri. 2014. Pengembangan Bahan Ajar Berbasis Guided Inquiry dengan Representasi Chemistry Triangle pada Materi Asam dan Basa Kelas XI SMA/MA. Prosiding ISBN 978-602-70491-0-9, SEMIRATA 2014 Bidang MIPA BKS-PTN-Barat, IPB : 50-58.

Kementrian Pendidikan Nasional. 2014. Konsep dan Implementasi Kurikulum 2013. Jakarta: Kementrian Pendidikan dan Kebudayaan

Kurinasih, Imas dan Berlin Sami. 2014. Implementasi Kurikulum 2013 Konsep dan Penerapan. Surabaya: Kata Pena

Mudjijo. 1995. Tes Hasil Belajar. Jakarta: Bumi Aksara

Myers, Monypenny, \& Trevathan. 2012. Overcoming the glassy-eyed nod: an application of process-oriented guided inquiry learning techniques in information technology. JLD, 5(1): 12-22

Patrick, H.,dkk.2009. Motivation for Learning Science in Kindergarten: Is There a Gender Gap and Does Integrated Inquiry and Literacy Instruction Make a Difference. Journal Of Research In Science Teaching. Vol. 46 (2): 166-191

Rochmad. 2011. model Pengembangan Perangkat Pembelajaran Matematika, DesainModel Pengembangan. Online. http://www. scribd. com/ doc/ 78603100/

Sanjaya, Wina. 2006. Strategi Pembelajaran Berorientasi Standar Proses Pendidikan. Jakarta: Kencana Prenada Media Group

Silabus Mata Pelajaran Kimia Untuk SMA. 2013.

Straumanis, Andrei. 2010. Process Oriented Guided Inquiry Learning. A Practical Guide For Instruktor, Organic Chemistry: Guided Inquiry, Second Edition. USA: Brool/Cole.

Sugiyono. 2008. Metode Penelitian Pendidikan. Bandung: Alfabeta
Sugiyono. 2011. Metode Penelitian Pendidikan. Bandung: Alfabeta

Sukardi. 2011. Evaluasi Pendidikan, Prinsip, Dan Operasionalnya. Yogyakarta: Bumi Aksara.

Trianto. 2012. Model Pembelajaran Terpadu. Jakarta: Bumi Aksara.

Yusuf, Syamsu dan Nani Sugandhi.2011. Perkembangan Peserta Didik. Jakarta: PT Raja Grafindo Persada. 